\title{
PELATIHAN PENULISAN ARTIKEL ILMIAH BAGI GURU KIMIA DI KABUPATEN KARANGASEM
}

\author{
oleh \\ I Wayan Redhana, I Made Kirna, dan I Nyoman Suardana \\ Jurusan Pendidikan Kimia \\ Fakultas Matematika dan Ilmu Pengetahuan Alam \\ Universitas Pendidikan Ganesha
}

\begin{abstract}
ABSTRAK
Tujuan kegiatan P2M ini adalah menghasilkan produk berupa artikel ilmiah yang siap diterbitkan dalam Jurnal Pendidikan Kimia Indonesia (JPKimIa). Untuk mencapai tujuan tersebut, dilakukan kegiatan pelatihan penulisan artkel ilmiah kepada guru-guru kimia yang tergabung dalam MGMP Kimia Kabupaten Karangasem. Kegiatan pelatihan yang dilakukan diawali dengan berkoordinasi dengan MGMP Kimia Kabupaten Karangasem mengenai jadwal dan tempat pelaksanaan P2M, pelatihan pencarian informasi atau browsing internet, pembekalan penulisan artikel ilmiah, pelatihan menganalisis artikel, dan pembuatan artikel ilmiah. Kegiatan dirancang selama satu bulan penuh dari tanggal 23 September sampai dengan tanggal 31 Oktober 2012 yang dilaksanakan di SMAN 1 Amplapura. Kegiatan pembekalan tentang pencarian informasi atau browsing internet, penulisan proposal penelitian tindakan kelas, penulisan artikel ilmiah, analisis artikel, dan pembuatan artikel ilmiah dilakukan pada tanggal 23 Septermber 2012. Jumlah peserta yang hadir pada kegiatan pembekalan tersebut ini sebanyak 16 orang dari 30 orang yang diundang. Pada pembekalan ini, peserta sangat antusias bertanya, tidak saja berkaitan dengan artikel yang akan dibuat, tetapi juga berkaitan dengan penelitian tindakan kelas. Setelah itu dilanjutkan dengan penulisan artikel yang dibimbing oleh dosen-dosen yang terlibat dalam kegiatan P2M ini. Penulisan artikel dilanjutkan di rumah masing-masing selama satu bulan. Selama penulisan artikel ini, peserta dapat berkonsultasi melalui telepon atau email. Kemudian, pada tanggal 31 Oktober 2012 peserta hadir membawa artikel yang telah dibuat dalam kegiatan pembimbingan. Jumlah peserta yang hadir pada kegiatan ini sebanyak 11 orang dari 30 orang yang diundang. Pada kegiatan ini peserta diberikan kesempatan untuk menanyakan masalah-masalah yang dihadapi berkaitan dengan penulisan artikel. Jumlah artikel yang dapat dikumpulkan pada kegiatan ini sebanyak enam buah artikel.
\end{abstract}

Kata-kata kunci: pelatihan, artikel, guru kimia

\section{Pendahuluan}

Jabatan fungsional guru adalah jabatan fungsional yang mempunyai ruang lingkup, tugas, tanggung jawab, dan wewenang untuk melakukan kegiatan mendidik, mengajar, membimbing, mengarahkan, melatih, menilai, dan mengevaluasi peserta didik pada pendidikan anak usia dini jalur pendidikan formal, pendidikan dasar, dan pendidikan 
menengah sesuai dengan peraturan perundang-undangan yang diduduki oleh Pegawai Negeri Sipil. Guru adalah pendidik profesional dengan tugas utama mendidik, mengajar, membimbing, mengarahkan, melatih, menilai, dan mengevaluasi peserta didik pada pendidikan anak usia dini jalur pendidikan formal, pendidikan dasar, dan pendidikan menengah. Oleh karena itu, peranan guru dalam memajukan pendidikan dan dalam menyiapkan sumber daya manusia yang berkualitas sangat penting dan strategi.

Mengingat pentingnya peranan guru dalam memajukan pendidikan nasional dan menyiapkan sumber daya manusia yang berkualitas, guru yang berkualitas di masa sekarang dan di masa yang akan datang mutlak diperlukan. Untuk itu, pemerintah melalui Menteri Negara Pendayaan Aparatur Negara mengeluarkan Permenegpan Nomor 16 Tahun 2009 tentang Jabatan Angka Fungsional Guru dan Angka Kreditnya. Unsur dan sub unsur kegiatan guru yang dinilai angka kreditnya meliputi pendidikan, pembelajaran/ pembimbingan, pengembangan keprofesian berkelanjutan, dan penunjang. Pengembangan keprofesian berkelanjutan meliputi sub unsur pengembangan diri, publikasi ilmiah, dan karya inovatif. Publikasi ilmiah dapat meliputi publikasi ilmiah atas hasil penelitian atau gagasan inovatif pada bidang pendidikan formal dan publikasi buku teks pelajaran. Pada Pasal 16 Ayat (2) dinyatakan bahwa "Untuk kenaikan jabatan/pangkat setingkat lebih tinggi dari guru pertama, pangkat penata muda, golongan ruang IIIa sampai dengan guru utama, pangkat pembina utama, golongan ruang IVe wajib melakukan kegiatan pengembangan keprofesian berkelanjutan yang meliputi sub unsur pengembangan diri, publikasi ilmiah, dan/atau karya inovatif." Peraturan ini mulai berlaku 1 Januari 2011. Ini menyisyaratkan kepada kita bahwa guru-guru harus melakukan pengembangan diri jika mengusulkan kenaikan jabatan/pangkat. Salah satu pengembangan diri yang dapat dilakukan oleh guru-guru adalah dengan membuat karya ilmiah yang dipublikasikan dalam jurnal ilmiah.

Untuk membantu guru-guru kimia alumni Jurusan Pendidikan Kimia dalam mempublikasikan hasil-hasil penelitian atau gagasan pemikiran kritisnya, Ikatan Alumni Jurusan Pendidikan Kimia (IKA-Kim) FMIPA Universitas Pendidikan Ganesha (Undiksha) membuat suatu wadah komunikasi ilmiah yang berupa jurnal ilmiah. Jurnal ini kemudian diberi nama Jurnal Pendidikan Kimia Indonesia (disingkat JPKimIa). Dalam perkembangannya, keberadaan jurnal ini tidak hanya untuk menampung hasilhasil penelitian dari guru-guru kimia alumni Jurusan Pendidikan Kimia Undiksha, tetapi 
juga untuk mempublikasikan karya dari seluruh peneliti, praktisi, pemerhati pendidikan, dan pengembang kurikulum, khususnya dalam bidang pendidikan kimia. Melalui media komunikasi berupa JPKimIa ini, para peneliti dan praktisi dalam bidang pendidikan kimia dapat menyebarluaskan hasil-hasil penelitian dan gagasannya kepada masyarakat ilmiah sehingga masyarakat ilmiah dapat mengimplementasikan hasil-hasil penelitian atau gagasan kritis tersebut untuk meningkatkan kualitas pendidikan di negara kita. Selain oleh guru-guru kimia, hasil-hasil penelitian yang dipublikasikan dalam JPKimIa ini juga dapat dimanfaatkan oleh semua pemangku kepentingan, termasuk dinas pendidikan dan perguruan tinggi dalam rangka meningkatkan kualitas pendidikan.

JPKimIa terbit dua kali yaitu periode April dan Oktober setiap tahunnya. Setiap terbitan memerlukan sekitar 10 artikel. Untuk memperoleh jumlah 10 artikel setiap terbitan atau nomor tentu bukan pekerjaan yang mudah. Memang ada kebijakan di Jurusan Pendidikan Kimia bahwa kekurangan artikel akan dipenuhi dari artikel skripsi mahasiswa S1. Selain itu, kekurangan artikel setiap terbitan akan di-back up oleh artikel dari dosen-dosen di Jurusan Pendidikan Kimia. Kenyataannya, jumlah artikel yang diharapkan dari guru-guru kimia alumni Jurusan Pendidikan Kimia sangat kurang. Apa yang menjadi harapan ketika JPKimIa di bentuk yaitu mewadahi hasil-hasil penelitian atau gagasan dari guru-guru kimia, tidak dapat terpenuhi. Dari dua nomor yang sudah terbit, kebanyakan tulisan berasal dari dosen-dosen dan mahasiswa Jurusan Pendidikan Kimia yang telah menyelesaikan skripsi. Jurusan Pendidikan Kimia memang mewajibkan kepada mahasiswa agar membuat artikel hasil penelitian dari skripsinya. Artikel inilah yang sementara menjadi penopang pemenuhan artikel JPKimIa.

Direktorat Jenderal Pendidikan Tinggi (Ditjen Dikti) Kementerian Pendidikan dan Kebudayaan mengeluarkan Surat Edaran Nomor 152/E/T/2012 tentang Publikasi Karya Ilmiah. Isi surat edaran tersebut adalah sebagai berikut. Pertama, untuk lulus program sarjana, mahasiswa harus telah menghasilkan makalah yang terbit pada jurnal ilmiah. Kedua, untuk lulus program magister, mahasiswa harus telah menghasilkan makalah yang terbit pada jurnal ilmiah nasional, diutamakan yang terakreditasi Dikti. Ketiga, untuk lulus program doktor, mahasiswa harus telah menghasilkan makalah yang terbit pada jurnal internasional. Ketentuan ini merupakan pemecahan atas masalah paceklik publikasi ilmiah. Pemerintah berasumsi bahwa pengejaran kuantitas publikasi ilmiah dapat dijadikan indikasi peningkatan kualitas karya ilmiah. 
Berkaitan dengan surat edaran ini, mahasiswa Jurusan Pendidikan Kimia telah memiliki wadah untuk menerbitkan artikel skripsinya dalam JPKimIa. Oleh karena itu, kehadiran dari JPKimIa ini juga merupakan solusi bagi mahasiswa Jurusan Pendidikan Kimia yang mungkin akan sulit menerbitkan artikelnya hasil penelitian skripsinya. Ini berarti, JPKimia tidak akan kekurangan artikel untuk setiap terbitan, paling tidak disuplai oleh artikel dari hasil penelitian skripsi mahasiswa di Jurusan Pendidikan Kimia. Namun, jurnal yang baik adalah jurnal yang mempublikasikan artikel yang berasal dari luar. Dengan kata lain, jurnal tidak hanya memuat artikel dari dalam atau kalangan sendri (Jurusan Pendidikan Kimia Undiksha), tetapi juga memuat artikel dari luar. Salah satu syarat jurnal agar bisa diakreditasi oleh Dikti adalah artikel yang dimuat paling tidak $60 \%$ berasal dari luar. Ini tentu pekerjaan yang tidak mudah.

Untuk dapat memenuhi kebutuhan artikel yang berasal dari luar, pihak pengelola perlu melakukan sosialisasi JPKimIa kepada penulis luar. Untuk hal ini, sosialisasi telah dilakukan kepada guru-guru kimia yang ada di propinsi Bali, Jawa Timur, dan Nusa Tenggara Barat, dan Nusa Tenggara Timur ketika rapat IKA-Kim. Pengelola juga telah melakukan sosialisasi JPKimIa ke universitas di luar Undiksha, seperti Universitas Pendidikan Indonesia, Universitas Negeri Semarang, Universitas Negeri Surabaya, dan Universitas Sri Wijaya dengan cara mengirimkan contoh terbitan JPKimIa kepada salah satu dosen di universitas tersebut dan mengimbau dosen yang bersangkutan akan mengarahkan mahasiswa menulis artikel di JPKimIa. Pengelola juga telah membuat web JPKimIa (masih offline), namun belum bisa di-upload ke web Undiksha dengan alasan birokrasi. Karena JPKimIa belum terakreditasi, para penulis masih enggan memasukkan artilkel atau tulisannya.

Penulis luar yang paling layak disasar adalah guru-guru kimia alumni Jurusan Pendidikan Kimia Undiksha yang ada di propinsi Bali. Namun, secara umum kemampuan guru-guru kimia menulis artikel ilmiah masih sangat rendah. Untuk itu, melalui kegiatan Pengabdian kepada Masyarakat (P2M) ini, pengelola memberikan pelatihan tentang penulisan artikel ilmiah bagi guru-guru kimia. Mengingat jangkauan dan jumlah guru-guru kimia sangat banyak, kegiatan pelatihan ini dilakukan secara bertahap, yaitu setiap tahunnya dilaksanakan pelatihan di satu kabupaten/kota. Pada tahun 2011, kegiatan pelatihan penulisan artikel bagi guru-guru kimia ini telah dilakukan di kabupaten Gianyar. Dari kegiatan di kabupaten Gianyar ini telah dihasilkan 
dua artikel yang telah terbit di JPKimia. Untuk tahun 2012 ini, kegiatan P2M diarahkan untuk memberikan pelatihan penulisan artikel ilmiah bagi guru-guru kimia di kabupaten Karangasem.

Kemampuan guru-guru kimia yang ada di kabupaten Karangasem dalam menulis karya ilmiah secara umum masih sangat rendah, walaupun diakui bahwa beberapa guruguru kimia telah memiliki kemampuan menulis karya ilmiah yang sangat memadai. Beberapa dari mereka bahkan menjadi guru teladan di tingkat propinsi dan nasional dan juga memenangkan lomba karya ilmiah (penelitian tindakan kelas) di tingkat nasional. Namun, keberhasilan beberapa orang guru kimia ini tidak diikuti oleh guru lainnya. Beberapa permasalahan yang dapat diidentifikasi berkaitan dengan rendahnya kemampuan guru-guru kimia di kabupaten Karangasem menulis artikel ilmiah dapat diuraikan sebagai berikut.

Pertama, guru-guru kimia kurang memiliki sumber-sumber informasi, seperti buku dan jurnal. Hal ini dikemukakan oleh beberapa orang guru kimia bahwa mereka tidak memiliki buku atau jurnal sehingga mereka tidak dapat mendukung tulisannya dengan teori-teori yang ada. Demikian juga tidak ada perpustakaan di daerah mereka. Walaupun mereka tidak memiliki sumber informasi yang memadai atau tidak terdapat perpustakaan di daerah mereka yang khusus menyediakan buku-buku pendidikan, mereka sesungguhnya dapat mengakses atau browsing informasi di internet. Asalkan mereka dapat menuliskan kata-kata kunci dengan tepat, mereka akan memperoleh informasi dimaksud dengan cepat. Beberapa sekolah terutama Rintisan Sekolah Bertaraf Internasional (RSBI) telah memiliki jaringan internet di sekolahnya. Namun, mereka belum bisa memanfaatkan jaringan internet ini secara maksimal karena mereka kebingungan atau tidak mengetahui cara mengangkses informasi dengan cepat dan tepat. Akibatnya, mereka seperti ayam bertelur di padi, namun mati kelaparan. Artinya, fasilitas internet sudah tersedia, namun mereka belum bisa memanfaatkan fasilitas internet tersebut secara optimal.

Kedua, guru-guru kimia umumnya tidak memiliki hasil penelitian atau gagasan untuk ditulis. Hal ini sangat berkaitan dengan masalah pertama yaitu kurangnya tersedia sumber informasi berupa buku dan jurnal tentang pendidikan. Walaupun guru-guru kimia tidak memiliki hasil penelitian untuk ditulis, mereka dapat menulis gagasan inovatifnya. Gagasan ini dapat diperoleh dari membaca hasil-hasil penelitian atau 
gagasan pemikiran orang lain. Masalah utama adalah mereka malas membaca materi yang berkaitan dengan pendidikan kimia.

Ketiga, kemampuan guru-guru kimia dalam menulis atau menuangkan ide dalam tulisan secara umum sangat rendah. Guru-guru kimia umumnya tidak terbiasa menulis. Pekerjaan menulis, dalam hal ini artikel ilmiah, memerlukan latihan dan pembiasaan. Keterampilan menulis ini tidaklah dibawa sejak lahir, melainkan diperoleh melalui proses pembelajaran dan latihan. Orang memiliki keterampilan menulis artikel ilmiah karena mereka berlatih menulis artikel. Hasil tulisannya pasti kurang baik pada awal mereka belajar menulis. Seiring dengan waktu dan latihan yang keras dan sungguhsungguh mereka akan dapat melahirkan artikel berkualitas.

Terakhir, guru-guru kimia tidak memahami aturan tata tulis ilmiah dalam jurnal ilmiah. Mereka membuat judul sangat panjang, bahkan mereka mengkopi judul penelitian menjadi judul artikel. Masalah lainnya adalah pembuatan abstrak. Mereka membuat abstrak lebih dari 200 kata, bahkan satu halaman dengan spasi tunggal. Demikian juga dengan jumlah kata-kata kunci. Mereka membuat kata-kata kunci lebih dari lima. Pada bagian pendahuluan, mereka menguraikan terlalu panjang lebar teori dan mereka sering mengambil kalimat atau paragraf dari buku atau tulisan orang lain tanpa menyebutkan sumbernya. Di samping itu, tulisan yang dibuat oleh guru-guru kimia sering tidak berkaitan antara paragraf yang satu dengan paragraf yang lain. Sementara itu pada metode penelitian, mereka menulis desain penelitian tidak jelas. Untuk bagian hasil dan pembahasan mereka tidak menyajikan hasil secara ringkas. Rerata tidak disertai standar deviasi. Demikian juga sering terjadi penyajian ganda, data yang sama disajikan dalam berbagai bentuk. Artinya, data sudah disajikan dalam bentuk tabel, juga disajikan dalam bentuk grafik. Dalam hal pembahasan, guru-guru tidak membahas temuan secara mendalam, melainkan menarasikan temuan atau hasil secara panjang lebar. Demikian juga guru-guru kimia kurang membandingkan temuannya dengan temuan lain yang dihasilkan oleh peneliti lain.

Kondisi di atas akan menjadikan guru-guru kimia sebagai konsumen ide, bukan sebagai produsen ide. Guru-guru kimia hendaknya dapat menghasilkan ide-ide atau gagasan inovatif yang dapat dibagi (di-sharing) kepada sesama profesi. Jika setiap orang guru kimia dapat menghasilkan ide-ide inovatif dan membaginya kepada guruguru kimia lain, maka ide-ide tersebut akan dapat dimiliki oleh guru-guru lain. Dengan 
kata lain, proses berbagi (memberi dan menerima) akan dapat berlangsung dengan baik. Inilah yang sesungguhnya disebut sebagai masyarakat ilmiah dan masyarakat belajar (learning community).

Luaran yang diharapkan dari kegiatan P2M ini adalah artikel ilmiah yang siap dipublikasikan di JPKimIa. Dengan demikian, rumusan permasalahan yang akan dicari jawabannya setelah guru-guru kimia mengikuti kegiatan P2M ini adalah sebagai berikut. (1) Berapa jumlah produk artikel ilmiah yang dapat dihasilkan oleh guru-guru kimia di kabupaten Karangasem yang siap dipublikasikan dalam JPKimIa?, dan (2) Bagaimana kualitas artikel ilmiah yang dihasilkan oleh guru-guru kimia di kabupaten Karangasem?

\section{Metode Pelaksanaan Pengabdian}

Pemecahan masalah di atas didekati dengan menggunakan kerangka berpikir, seperti ditunjukkan di bawah. Masalah yang ada di lapangan diidentifikasi, kemudian dirumuskan alternatif pemecahan masalahnya. Kemudian, dari alternatif pemecahan masalah yang berhasil diidentifikasi, dipilih alternatif yang paling mungkin dan tepat sasaran untuk mengatasi masalah yang ada. Setelah memilih alternatif yang paling mungkin dan tepat sasaran, selanjutnya dirumuskan metode kegiatan/pelaksanaan pemecahan masalah. Metode pelaksanaan kegiatan berupa pelatihan. Kegiatan pelatihan penulisan artikel ilmiah dilakukan dengan langkah-langkah sebagai berikut.

Penulis berkoordinasi dengan pengurus MGMP Kimia kabupaten Karangasem berkaitan dengan kegiatan pelatihan, terutama mengenai tempat dan jadwal pelaksanaan. Kegiatan pelatihan ini kan dilaksanakan pada tanggal 23 September2012 sampai Oktober 2012. Pengurus MGMP diharapkan dapat membantu penulis menyiapkan prasarana dan sarana penunjang pelaksanaan kegiatan pelatihan. Pengurus MGMP juga menyurati anggota MGMP untuk menjadi peserta dalam kegiatan pelatihan. Jumlah guru-guru kimia yang diundang sebanyak 30 orang.

Kegiatan ini diawali dengan pemberian informasi atau pembekalan kepada seluruh peserta tentang cara-cara dan trik-trik cepat pencarian informasi yang berkaitan dengan artikel jurnal, buku, makalah, materi bidang studi, animasi dan video pembelajaran, dan sebagainya di internet. Setelah pembekalan, seluruh peserta berlatih mengakses informasi di internet. 


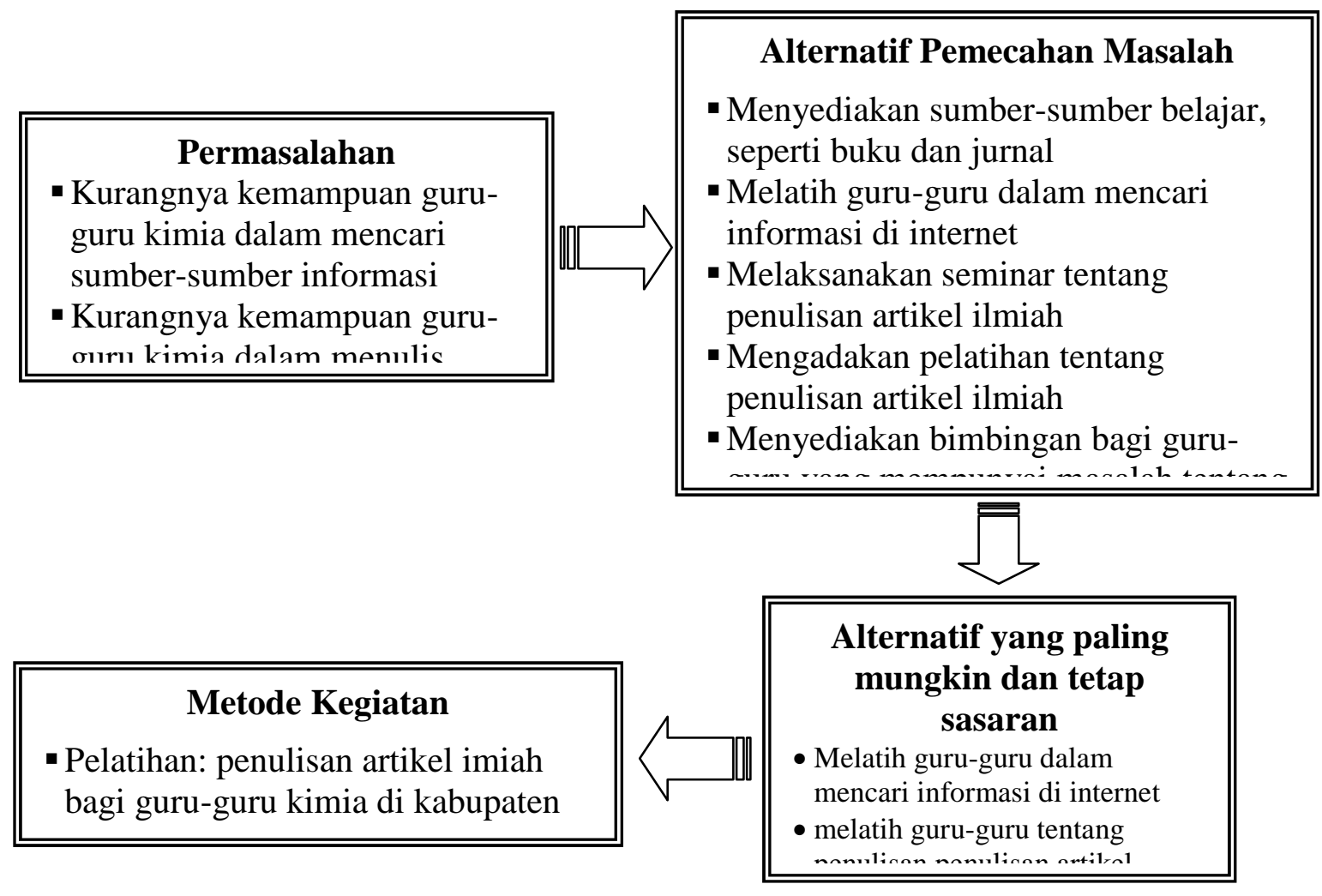

Gambar 1. Bagan Skematis Kerangka Pemecahan Masalah

Penelitian tindakan kelas merupakan kegiatan wajib yang harus dilakukan oleh guru-guru sebagai bagian dari kegiatan pembelajaran yang dilakukan. Oleh karena itu, dipandang perlu untuk memberikan penulisan proposal penelitian tindakan kelas. Hal ini disebabkan oleh dengan adanya penelitian yang dilakukan oleh guru, maka guruguru akan memiliki penelitian yang nantinya dapat ditulis menjadi artikel penelitian. Pembekalan penulisan proposal penelitian tindakan kelas meliputi tentang penulisan judul, latar belakang masalah, rumusan masalah, tujuan dan manfaat penelitian, kajian pustaka, hipotesis penelitian, metode penelitian, daftar rujukan, jadwal dan anggaran. Pada bagian metode penelitian disampaikan tentang subjek dan objek penelitian, rancangan penelitian, prosedur penelitian, instrumen penelitian, dan teknik analisis data. 
Pembekalan penulisan artikel ilmiah meliputi tentang pedoman penulisan pada JPKimIa. Untuk artikel hasil penelitian, cakupan materinya meliputi kriteria judul, identitas penulis, abstrak, pendahuluan, metode penelitian, hasil dan pembahasan, penutup, dan daftar rujukan. Sementara itu, untuk artikel kajian putaka atau hasil gagasan, cakupan materinya meliputi kriteria judul, identitas penulis, abstrak, pendahuluan, pembahasan, penutup, dan daftar rujukan. Penulisan daftar rujukan menggunakan sistem American Phsychological Association (APA) meliputi antara lain: (1) penulisan buku cetakan dengan satu penulis, (2) buku cetakan dengan dua penulis, (3) buku cetakan dengan editor sebagai penulis, (4) buku review cetakan dengan dua orang penulis, (5) brosur cetakan tanpa tahun dan tanpa penulis, (6) bab dalam buku cetakan yang ada editornya, (7) bab dalam buku cetakan yang ada edisi dan editornya, (8) disertasi/tesis/skripsi yang tidak dipublikasikan yang ada dalam database, (9) laporan pemerintah/koorporasi yang publikasikan secara online, (10) artikel jurnal dengan dua orang penulis yang dipublikasikan secara online dan mengandung doi (digital object installer), (11) artikel jurnal cetakan dengan satu orang penulis, (12) artikel jurnal yang dipublikasikan secara online oleh dua orang penulis, tanpa doi, (13) artikel jurnal oleh tiga sampai enam orang penulis yang dipublikasikan secara online dengan doi, (14) artikel jurnal cetakan oleh tujuh atau lebih orang penulis, (15) karya individu di internet, (16) artikel jurnal di internet, (17) artikel majalah cetakan, (18) artikel majalah online yang ditemukan dalam database tanpa doi, (19) artikel jurnal dalam CD-ROM, (20) artikel koran online tanpa doi, (21) artikel koran cetakan dengan penulis, (22) artikel koran cetakan tanpa penulis, (23) makalah atau poster yang dipresentasikan dalam pertemuan, (24) dokumen resmi pemerintah yang diterbitkan oleh suatu penerbit tanpa penulis dan tanpa lembaga, (25) lembaga yang ditulis atas nama lembaga tersebut, (26) karya terjemahan, skripsi, tesis, dan disertasi, (27) makalah yang disajikan dalam seminar, penataran atau lokakarya, (28) bahan diskusi di internet, (29) email pribadi, (30) website tanpa penulis dan tanpa tahun, (31) makalah dipresentasikan dalam pertemuan, dan (32) abstrak diakses onlie tanpa doi.

Materi berikutnya adalah cara pengutipan. Jenis kutipan terdiri atas: (1) satu pekerjaan oleh satu orang penulis, (2) satu pekerjaan oleh dua orang penulis, (3) satu pekerjaan oleh tiga orang penulis, (4) satu pekerjaan oleh empat orang penulis, (5) satu pekerjaan oleh lima orang penulis, (6) satu pekerjaan oleh enam orang penulis atau 
lebih, (7) kelompok (ada singkatan sebagai penulis), (8) kelompok (tanpa singkatan sebagai penulis). Selain itu, juga dipaparkan materi tentang penggunaan "dan" versus "\&," cara pengutipan, dan penggunaan bahasa dan tanda baca.

Setelah peserta diberi pembekalan tentang materi penulisan artikel ilmiah, peserta selanjutnya berlatih menilai artikel yang masuk ke meja redaksi. Peserta diminta menerapkan pengetahuan yang dimiliki untuk menilai artikel jurnal. Kegiatan selanjutnya adalah peserta menulis artikel ilmiah berdasarkan hasil-hasil penelitian atau gagasan ilmiahnya. Selama penulisan ini peserta dibimbing oleh pelatih (pelaksana P2M). Kegiatan penulisan ini dilanjutkan di rumah masing-masing peserta dan mereka diminta sudah membawa artikel akhir pada bulan berikutnya guna diberikan masukanmasukan untuk menyempurnakan artikel tersebut. Kegiatan P2M ini sangat berkaitan dengan upaya pengembangan profesionalisme guru-guru kimia (MGMP kimia kabupaten Karangasem). Dengan kegiatan pelatihan ini, guru-guru kimia memiliki pengetahuan dan keterampilan membuat artikel ilmiah sehingga hasil-hasil penelitian dan gagasan pemikirannya dapat disebarluaskan kepada masyarakat ilmiah. Para pembaca dapat mengimplementasikan hasil-hasil penelitian dan gagasan tersebut sehingga kualitas pendidikan yang berlangsung menjadi lebih baik. Pada gilirannya nanti adalah peningkatan kualitas hasil belajaran siswa.

Keberhasilan dari kegiatan pelatihan penulisan artikel ilmiah bagi guru-guru kimia di kabupaten Karangasem dilihat dari kuantitas dan kualitas produk artikel ilmiah yang dihasilkan dari kegiatan pelatihan tersebut. Tabel 1 menyajikan aspek yang dievaluasi dan kriteria indikator pencapaian tujuan. Jumlah peserta pelatihan sekitar tiga puluh orang guru kimia. Dengan asumsi setiap guru kimia membuat satu artikel ilmiah, dengan demikian akan minimal akan ada 6 artikel yang siap dipublikasikan dalam JPKimIa. Sementara itu, untuk penilaian artikel menggunakan rubrik. Rubrik ini dibuat dengan mengadaptasi rubrik yang dikembangkan oleh tim pengelola Jurnal Ilmu Pendidikan (Universitas Negeri Malang). 
Tabel 1. Rancangan evaluasi

\begin{tabular}{|c|c|}
\hline a. Aspek yang dievaluasi & a. Indikator pencapaian tujuan \\
\hline \multirow[t]{2}{*}{$\begin{array}{l}\text { b. Artikel ilmiah yang dihasilkan } \\
\text { oleh guru-guru kimia selama } \\
\text { kegiatan P2M }\end{array}$} & $\begin{array}{l}\text { b. Jumlah artikel yang siap dipublikasikan } \\
\text { dalam JPKimIa paling tidak } 20 \% \text { dari jumlah } \\
\text { peserta pelatihan }\end{array}$ \\
\hline & $\begin{array}{l}\text { c. Rara-rata kualitas artikel yang dihasilkan dari } \\
\text { kegiatan pelatihan minimum tergolong baik, } \\
\text { dengan skor minimal } 70 \text {. }\end{array}$ \\
\hline
\end{tabular}

\section{Hasil dan Pembahasan}

Jumlah peserta yang hadir pada saat kegiatan pembekalan materi tentang pencarian informasi atau browsing internet, penulisan proposal penelitian tindakan kelas, penulisan artikel ilmiah, analisis artikel, dan pembuatan artikel ilmiah pada tanggal 23 September 2012 sebanyak 16 orang guru kimia dari 30 orang guru yang diundang. Pada kegiatan pembekalan ini peserta sangat antusias mengikuti materi pembekalan terutama untuk materi penelitian tindakan kelas. Kenyataannya, peserta cukup sering mengikuti pelatihan tentang penulisan proposal tindakan kelas, namun mereka masih mengalami kebingungan dalam hal memilih model pembelajaran dan mengembangkan perangkat pembelajaran serta membuat instrumen penelitian. Walaupun beberapa dari mereka telah mengikuti pendidikan S2, mereka masih belum memahami hakekat dari penelitian tindakan kelas.

Kesulitan yang paling mendasar dialami oleh guru-guru kimia di kabupaten Karangasem adalah menulis proposal. Hal ini disebabkan oleh mereka tidak terbiasa menulis. Kesulian ini juga dialami oleh guru-guru ketika mereka menulis artikel ilmiah. Artikel yang baik akan dilahirkan dari laporan penelitian yang baik. Laporan penelitian ini akan terlahir dari kegiatan penbelitian. Kegiatan penelitian akan terlaksana dari proposal penelitian. Kebanyakan guru-guru tidak mampu membuat proposal penelitian. Hal yang dilakukan oleh guru-guru adalah tidak membuat proposal, tetapi melaksanakan kegiatan penelitian dan membuat laporan penelitian. Kualitas laporan penelitian yang dibuat juga tergolong kurang. Akibatnya, kualitan artikel yang dihasilkan juga kurang.

Selama kegiatan penulisan artikel di rumah masing-masing, tidak ada guru yang memanfaatkan kegiatan konsultasi melalui telepon atau email. Hal ini disebabkan oleh beberapa hal. Pertama, mereka akan memanfaatkan kegiatan konsultasi pada saat 
pertemuan terakhir, yaitu pada tanggal 31 Oktober 2012. Kedua, sebagian dari guruguru tidak memiliki bahan untuk ditulis. Ketika kegiatan pada tanggal 31 Oktober 2012, jumlah guru-guru yang hadir sebanyak 11 orang. Pada kegiatan ini, sedikit guruguru yang memanfaatkan kegiatan konsultasi. Ada dua artikel yang ditulis dari laporan tesis. Tiga artikel dari kegiatan penelitian tindakan kelas dan satu artikel dalam bidang nonpendidikan, yaitu kimia murni (kajian teoritis). Jadi, total artikel yang diperoleh selama kegiatan ini sebanyak enam buah. Jumlah ini telah memenuhi target minimal yang dituntut dalam kegiatan P2M ini.

Dari artikel yang dikumpulkan, terdapat lima artikel bidang pendidikan dan satu artikel bidang nonpendidikan. Dari lima artikel bidang pendidikan, dua artikel merupakan penelitian eksperimen dan tiga artikel merupakan penelitian tindakan kelas. Kualitas artikel dapat diuraikan sebagai berikut. Satu artikel dengan kualitas sangat baik (skor 85), tiga artikel dengan kualitas baik (75), sisanya dengan kualitas cukup (60). Kelemahan yang berhasil diidentifikasi dari tulisan guru-guru adalah sebagai berikut. Masih ada jumlah kata dalam judul lebih dari 12 kata. Jumlah kata dalam abstrak lebih dari 300 kata. Demikian juga, mereka belum mampu menyajikan ide secara terstruktur dan sistematis. Dalam kaitannya dengan referensi, mereka menggunakan lebih banyak referenasi berupa buku atau sumber sekunder, bukan sumber primer. Untuk kemutahiran referensi, mereka masih menggunakan referensi yang tahunnya lebih dari 10 tahun. Guru-guru tidak mematuhi aturan penulisan daftar rujukan. Terakhir, jumlah halaman masih kurang dari yang diharapkan, yaitu sekitar 15 halaman. Ada dua artikel yang jumlah halamannya kurang dari 12 halaman.

Guru-guru kimia sangat antusias mengikuti kegiatan P2M. Mereka merasa memperoleh sesuatu yang baru. Namun, karena mereka tidak terbiasa menulis, mereka sangat sulit menghasilkan tuulisan. Mereka dapat memahami materi yang diberikan dengan baik. Namun ketika mereka menulis, mereka sering tidak mematuhi aturan tata tulis karya ilmiah. Sekali lagi, hal ini disebabkan oleh karena mereka tidak terbiasa menulis. Mereka sangat bersemangat ketika membahas tentang penelitian tindakan kelas. Hal ini disebabkan oleh setiap guru diharapkan melakukan penelitian tindakan kelas. Penelitian tindakan kelas harusnya menjadi bagian dari kegiatan pembelajaran guru. Hal ini dinyatakan secara implisit dalam Permendiknas No. 41 tahun 2007. Guru sangat antusias bertanya tentang hal iklwal yang berkaitan dengan penelitian tindakan 
kelas, seperti apa yang menjadi dasar dalam pemilihan model pembelajaran dan bagaimana mengembangkan perangkat pembelajaran dari model pembelajaran yang dipilih. Pertanyaan lainnya adalah bagaimana melakukan refleksi jika guru hendak melakukan penelitian tindakan kelas di kelas X pada awal semseter, sementara siswanya baru pertama kali menginjak SMA?

Peserta sangat puas dengan jawaban yang diberikan oleh instruktur. Namun, tetap saja mereka kesulitan dalam menulis. Mereka berjanji akan menulis artikel ilmiah dan menyelesaikannya pada pertemuan berikutnya. Pada pertemuan tanggal 31 Oktober 2012, beberapa guru telah membawa artikel yang sudah selesai. Sementara yang lain belum menyelesaikan artikelnya. Mereka akhirnya menyelesaikan artikel dari laporan tesis yang pernah mereka buat ketika mereka mengikuti pendidikan S2 di Undiksha. Dengan bimbingan yang disediakan oleh instruktur, akhirnya mereka dapat menyelesaikan artikel ilmiah, walaupun kualitasnya masih perlu ditingkatkan. Kegiatan menulis khususnya menulis artikel ilmiah bukanlah pekerjaan yang mudah. Untuk dapat menghasilkan tulisan yang baik, diperlukan latihan yang banyak. Kemampuan menulis ini tidak dapat diperoleh dalam waktu sngkat. Latihan ini memerlukan ketekunan dan kebiasaan. Keterampilan menulis adalah keterampilan yang tidak dibawa sejak lahir, tetapi keterampilan ini dapat dipelajari dan diajarkan.

\section{Penutup}

Jumlah guru yang berpartisipasi pada pertemuan tanggal 23 September 2012 dan 31 Oktober 2012 masing-masing sebanyak sebanyak 16 orang dan 11 orang. Dari 11 orang guru yang hadir pada pertemuan kedua dapat diperoleh artikel sebanyak enam buah, yang terdiri atas lima buah artikel pendidikan dan satiu artikel dalam bidang nonpendidikan. Dari lima artikel dalam bidang pendidikan, terdapat dua artikel untuk penelitian eksperimen dan tiga artikel untuk penelitian tindakan kelas. Kualitas artikel dapat diuraikan sebagai berikut. Satu artikel dengan kategori sangat baik, tiga artikel dengan kategori baik, dan sisanya tergolong katerori cukup (skor $<70$ ). Guru-guru kimia hendaknya meningkatkan kualitas tulisannya dengan meningkatkan frekuensi latihan menulis. Dengan cara itu, kualitas tulisan dapat ditingkatkan. Selain, itu, guruguru hendaknya banyak membaca referensi termasuk hasil-hasil penelitian yang dilakukan orang lain agar dapat menghasilkan ide-ide inovatif. 


\section{DAFTAR PUSTAKA}

Anonim (2010). Cara efektif mencari informasi di Google. Tersedia pada: http: http://internet-marketing-gratis.blogspot.com/2010/06/cara-efektif-mencariinformasi-di.html. Diakses pada tanggal 20 februari 2011

Anonim. (2010). EYD terbaru (Permendiknas Nomor 46 Tahun 2009). Yogyakarta: Pustaka Timur.

Chaer, A. (2011). Ragam bahasa ilmiah. Jakarta: Rineka Cipta.

Direktorat Jenderal Pendidikan Tinggi (Ditjen Dikti) Kementerian Pendidikan dan Kebudayaan mengeluarkan Surat Edaran Nomor 152/E/T/2012 tentang Publikasi Karya Ilmiah.

Jurnal Pendidikan Kimia Indonesia (2001). Alumni Jurusan Pendidikan Kimia Undiksha.

Peraturan Menteri Negara Pendayaan Aparatur Negara Nomor 16 Tahun 2009 tentang Jabatan Angka Fungsional Guru dan Angka Kreditnya.

Santoso, U. (2010). Kiat-kiat pemulisan artikel ilmiah dalam jurnal ilmiah internasional. tersedia pada: http://uripsantoso.wordpress.com/2008/06/04. Diakses tanggal 20 februari 2012.

Sugihastuti. (2000). Bahasa laporan penelitian. Yogyakarta: Pustaka Belajar.

Surat Edaran Direktorat Jenderal Pendidikan Tinggi Kementerian Pendidikan dan Kebudayaan No. 152/E/T/2012 Tanggal 27 Januari 2012 tentang Publikasi Karya Ilmiah.

Tanjung, H. B. N. \& Ardial, H. (2010). Pedoman penulisan karya ilmiah dan mempersiapkan diri menjadi penulis artikel ilmiah. Jakarta: Prenada Media Group. 